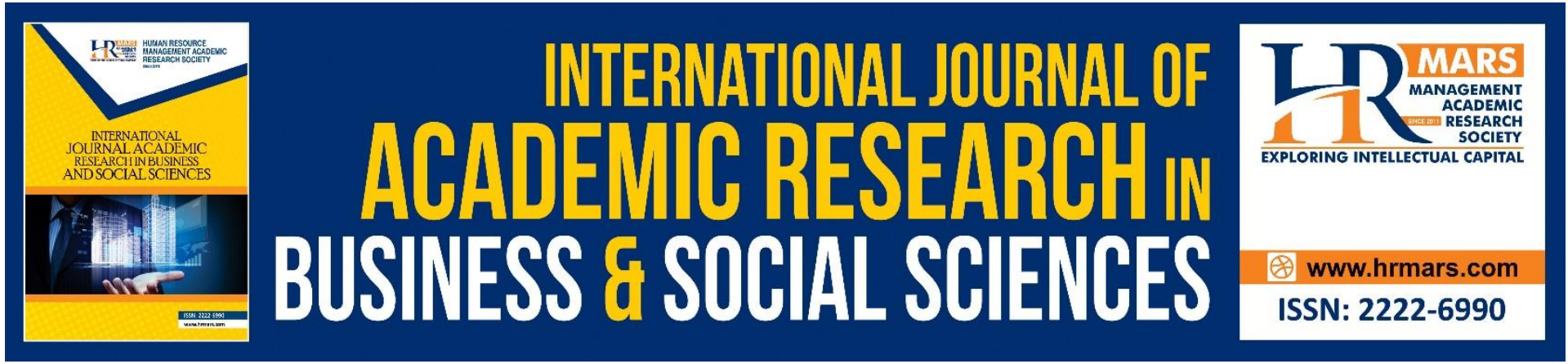

\title{
A Vocal Health Survey among Primary School Teachers in Klang Valley, Malaysia
}

\section{Dim Sy How and Mei Foong Ang}

To Link this Article: http://dx.doi.org/10.6007/IJARBSS/v11-i7/10412

DOI:10.6007/IJARBSS/v11-i7/10412

Received: 27 May 2021, Revised: 24 June 2021, Accepted: 13 July 2021

Published Online: 30 July 2021

In-Text Citation: (How \& Ang, 2021)

To Cite this Article: How, D. S., \& Ang, M. F. (2021). A Vocal Health Survey among Primary School Teachers in Klang Valley, Malaysia. International Journal of Academic Research in Business and Social Sciences, 11(7), 1687-1697.

\section{Copyright: @ 2021 The Author(s)}

Published by Human Resource Management Academic Research Society (www.hrmars.com)

This article is published under the Creative Commons Attribution (CC BY 4.0) license. Anyone may reproduce, distribute, translate and create derivative works of this article (for both commercial and non-commercial purposes), subject to full attribution to the original publication and authors. The full terms of this license may be seen at: http://creativecommons.org/licences/by/4.0/legalcode

Vol. 11, No. 7, 2021, Pg. 1687 - 1697

Full Terms \& Conditions of access and use can be found at http://hrmars.com/index.php/pages/detail/publication-ethics 


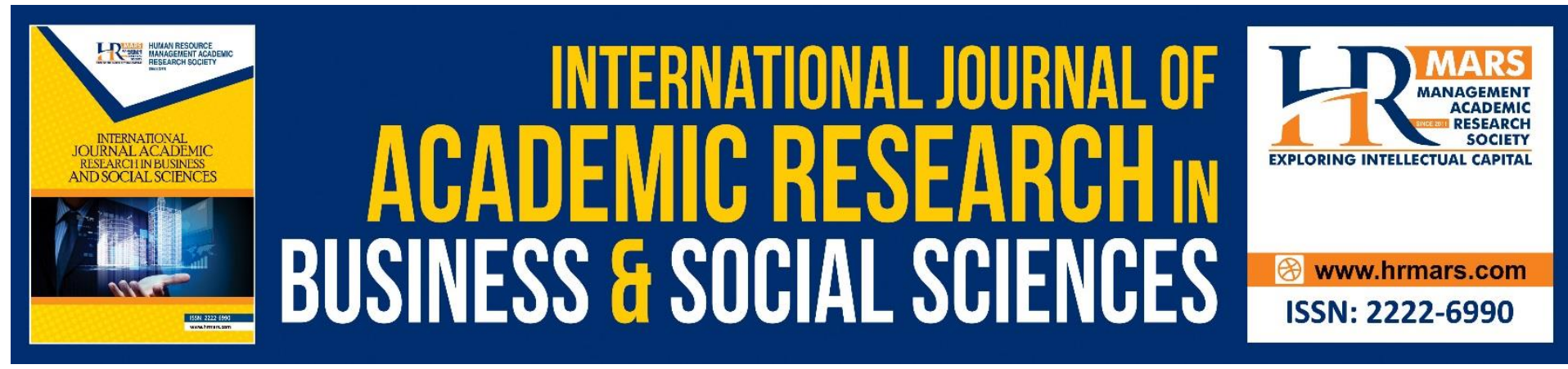

\title{
A Vocal Health Survey among Primary School Teachers in Klang Valley, Malaysia
}

\author{
Dim Sy How and Mei Foong Ang \\ Department of Music, Faculty of Human Ecology, Universiti Putra Malaysia, 43400 Sedang, \\ Malaysia, \\ Email: gs53348@student.upm.edu.my,meifoong@upm.edu.my
}

\begin{abstract}
Teachers are one of the highest demanding professional voice users. They are believed to have an increased risk of developing voice disorder, and the cause is often associated with several factors such as high vocal demands, unfavourable working conditions, lifestyle, and lack of knowledge in vocal health. Vocal disorder not only affects teachers in conducting and managing classes. It also affects their daily interaction with people and contributes to the decline of their physical and emotional health. This study aims to understand teachers' current vocal condition better and measure teachers' knowledge of vocal care. An online survey was conducted; 40 teachers, 33 females and 7 males, responded to the study. The study reviewed that teachers voice feels dry (51.22\%), sore $(24.39 \%)$ and pain $(12.20 \%)$ after a day of teaching and $78 \%$ of the teachers experience at least once vocal discomfort in a year. In conclusion, the insights and perception of vocal health base on self-report information of voice condition and lifestyle of teachers pertinent to this geographical location will be helpful in the development of vocal health programs for teachers in Malaysia.
\end{abstract}

\section{Introduction}

An individual was considered to have a healthy voice if one can produce a voice with ease and meet personal, professional, and social expectations. If a voice is used heavily, it can result in voice symptoms such as hoarseness, change in quality, fatigue, decreased pitch, and breathiness. This culmination of voice symptoms, once prolong, may lead to voice disorder (Porcaro et al., 2019; Sathyanarayan et al., 2018). Among the professional voice users, teachers depend highly on their voice for communication in their profession. Therefore, there is a high risk of developing vocal disorders compared to the general population (Roy, 2004).

Research on the prevalence of voice disorder among teachers was conducted in many countries such as Finland, Germany, New Zealand, America, and Korea, leaving solid and comprehensive national data. These data revealed that more than $50 \%$ of teachers reported having a vocal problem at least once in their lifetime (Nazari et al., 2020; Nussec et al., 2020; Vertanen-Greis, Loyttyniemi, \& Uitti, 2020), and the recurrent perceived of voice disorder after 3 years is $69.1 \%$ (Vertanen-Greis et al., 2020). 
In Malaysia, there are 2 relevant data; a study in Sarawak indicated that $53.8 \%$ of primary school teachers suffer from voice disorder in 12 months (Abdul Rahman, 2016), and another local study documented the prevalence of voice disorder among secondary school teachers is $10.4 \%$ (Sundram et al., 2019).

Significant factors that contributed to an increased risk of voice disorder included speaking for long hours in a poor acoustic environment, speaking loudly across a high level of classroom noise, continue to strain and yell during the period of inflammation, excessive throat clearing and dry coughing and speaking with a higher pitch for teachers who teach in kindergarten and primary school (Devadas, Bellur, \& Maruthy, 2017; Remacle, Morsomme, \& Finck, 2014). In addition, lifestyle, and habits such as improper diet, smoking, excessive consumption of alcohol, constant dehydration, posture, and alignment may also be the cause (Nallamuthu et al., 2021).

Vocal problems affect teacher's communicative capacity, teaching performance, impaired social functioning, and daily activities. Consequently, research has shown that voice disorder degrades teachers' engagement in their work, bringing a negative educational effect on students' performance. Findings were stating that dysphonic voice makes it harder for the listener to understand; hence, it decreases students' motivation to learn. According to research, $24.1 \%$ of the teachers call in sick because of voice problems, leading to financial burden to teachers on treatment for voice disorder and burden to school where substituted teachers were required while teachers are on sick leaves (Nazari et al., 2020; Smith et al., 1997).

Multiple studies have shown that teachers with voice complaints have a higher level of physical and mental exhaustion leading to $77 \%$ higher risk of common mental disorders (Mota et al., 2019; Rocha et al., 2021).

Voice disorder affects a teacher physically, emotionally, and socially. At present, the vocal health among primary school teachers in Klang Valley is undetermined. Therefore, a survey was designed to understand teachers' current vocal condition better and measure teacher's knowledge on vocal care.

\section{Materials and Methods}

A survey design was conducted among primary school teachers who teaches in Klang Valley. The survey in digital form was distributed from April - August 2019, and a total of 40 samples (33 females, 7 males) who teachers in Selangor and Kuala Lumpur were collected. The survey was created using Google form and was posted online. Convenient sampling will be used in this research because of its primary emphasis on generalizability.

The questionnaire was self-administered, and it consists of 44 multipart questions covering 5 significant areas. The areas included information on demographics, teachers working conditions, their lifestyle factors, vocal symptoms teachers encounter during teaching via daily conversation, teacher's vocal care.

Section A: General information including (a) gender, (b) age, (c) subjects taught, (c) total teaching hours per week, (d) years of service. 
Section B: Assess the working condition of teachers, which include questions such as (a) Number of students in class, (b)class flooring, (c)use of audio facilities, (d) use of ICT Facilities available

Section C: This section investigates the teacher's lifestyle in the context of diet (a)do they consume alcohol, (b) eat spicy food, (c) water intake per day, and if they smoke and hours of sleeping per day.

Section D: Investigate through scales from always, frequently, sometimes, rarely, and never on teacher vocal condition during teaching and daily conversations. Such as (a) breathy, (b) stop a phrase, (c) fatigues, (d) speaks too loudly, (e)speaks too soft, (f) voice crack, (g) throat hurts (h)voice is consistent daily (i) voice sounds clear.

Section E: In this section, knowledge of vocal care and precautions taken by the teacher when they encounter vocal symptoms were assessed with questions such as (a) what are the negative symptoms urge teachers for medical attention (b) how long does it take before teachers seek for medical attention (c) how frequent teachers encounter vocal symptoms in a year (d) what precautions teachers do to take care of their voice (c) if teachers know where to seek help if their voice has problems.

Research Question: (1) Is there a difference between teachers' voices during teaching and daily conversation? (2) How are the teacher's vocal conditions after a day of teaching? (3) How long does it take for a teacher to seek medical attention once they encounter voice discomfort.

\section{Results}

\section{General Information and Working Conditions}

40 primary school teachers participated in this study. There were $33(82.5 \%)$ females and $7(17.5 \%)$ males. Participants were mainly at the age between 30 to 39 years old $(n=14$, $35 \%)$. Most of the teachers work in Selangor $(n=25,62.5 \%)$. Participants teach between 4-40 hours per week $(M=19.1, S D=8.72), 14(35 \%)$ participants serve in the school between 5-14 years, $11(27.5 \%)$ serves more than 25 years, 9 serves between $15-24$ years $(22.5 \%)$, and 6 $(15 \%)$ serves less than 5 years. 
Table 2 presents the diet and lifestyle of teachers. 33 (85\%) respondents do not

Table 1 Social-demographic on research participants

\begin{tabular}{llcc}
\hline Factors & & Frequency $(\mathrm{n})$ & Percent (\%) \\
\hline Gender & Memale & 33 & 82.5 \\
& & 7 & 17.5 \\
Age & $<30$ & 6 & 15.0 \\
& $30-39$ & 14 & 35.0 \\
& $40-49$ & 7 & 17.5 \\
& $\geq 50$ & 13 & 32.5 \\
Location & & & \\
& Selangor & 25 & 62.5 \\
& Kuala & 15 & 37.5 \\
Total Teaching Hours & Lumpur & & \\
(Per week) & & & \\
& $10-19$ & 4 & 10.0 \\
& $20-29$ & 21 & 52.5 \\
& $30-40$ & 6 & 15.0 \\
Years of & & 8 & 20.0 \\
Service & $<5$ & 6 & \\
& $5-14$ & 14 & 15.0 \\
& $15-24$ & 9 & 22.5 \\
& $\geq 25$ & 11 & 27.5
\end{tabular}

consume alcohol, 7 (17.5\%) respondents only consume alcohol sometimes. None of them is a regular drinker, and all the respondents do not smoke. $24(60 \%)$ of the respondents take spicy food occasionally, 11 (27.5\%) take spicy food often, and 5 (12.5\%) respondents do not take spicy food. More than $50 \%$ of the respondents have $6-7$ sleep every day, and $65 \%$ of the respondents drink more than 1.5 litres of water every day. 
Table 2 Diet and lifestyle of research participants

\begin{tabular}{lccc}
\hline Variables & & Frequency (n) & Percentage (\%) \\
\hline Alcohol & Often & 0 & 0 \\
& No & 33 & 82.5 \\
& Sometimes & 7 & 17.5 \\
Smoking & Often & 0 & \\
& No & 40 & 0 \\
& Sometimes & 0 & 100 \\
Spicy Food & & & 0 \\
& Often & 11 & \\
& No & 5 & 27.5 \\
Sleeping Hours & Sometimes & 24 & 12.5 \\
(hours) & & & 60 \\
& $<6$ & 17 & \\
& $6-7$ & 21 & 42.5 \\
& $\geq 8$ & 2 & 52.5 \\
Water Intake (litres) & $<1$ & 3 & 5 \\
& $1-1.4$ & 11 & 7.5 \\
& $1.5-1.9$ & 15 & 27.5 \\
& $\geq 2$ & 11 & 37.5 \\
& & & 27.5 \\
\hline
\end{tabular}

Table 3 illustrated the comparison of teacher's voice during teacher and daily conversation under nine vocal condition of teacher includes breathy, stop in a phrase, fatigue, too loud, too soft, voice cracks, throat hurts, voice consistent daily and voice sounds clear. From table 3 , significant difference was found in fatigues $(t=2.662, p=0.011), p=$ $\leq 0.05$, throat hurts $(t=3.009, p=0.005), p=\leq 0.05$ and too loud $(t=2.662, p=0.054), p=\leq 0.05$ while other variables such as breathy $(t=0.868, p=0.391)$, stop in a phrase $(t=1.669, p=$ $0.103)$, too soft ( $t=-0.681, p=0.500)$. voice cracks ( $t=1.045, p=0.310)$, voice is consistent on daily basis ( $t=0.947, p=0.349)$ and voice sounds clear $(t=1.000, p=0.323)$ do not have a significant difference during teaching and daily conversation. 
Table 3 Comparison of teacher's voice during teaching and daily conversation

Voice

\begin{tabular}{lllll} 
Symptoms & Mean & SD & $t$ & $p$ value \\
\hline Breathy & 0.12500 & 0.91111 & 0.868 & 0.391 \\
Stop in a phrase & 0.20000 & 0.75786 & 1.669 & 0.103 \\
Fatigues & 0.42500 & 1.00989 & 2.662 & 0.011 \\
Too loud & 0.27500 & 0.87669 & 1.984 & 0.054 \\
Too soft & -0.10000 & 0.92819 & -0.681 & 0.500 \\
Voice cracks & 0.26316 & 1.09758 & 1.045 & 0.310 \\
$\begin{array}{l}\text { Throat hurts } \\
\text { Voice is }\end{array}$ & 0.35000 & 0.73554 & 3.009 & 0.005 \\
$\begin{array}{l}\text { consistent on } \\
\text { daily basis }\end{array}$ & 0.15000 & 1.00128 & 0.947 & 0.349 \\
$\begin{array}{l}\text { Voice sounds } \\
\text { clear }\end{array}$ & 0.17500 & 1.10680 & 1.000 & 0.323 \\
\hline
\end{tabular}

Respondents were asked about their vocal condition after teaching for a day, how frequent they experience vocal discomfort in a year, and how long they experienced vocal symptoms before seeking medical help. In Table 4, a total of $21(51.22 \%$, SD $=0.51)$ respondents reported they experience dryness after teaching for a day; $12(29.27 \%, S D=0.46)$ respondents have a clear voice; $10(24.39 \%, S D=0.43)$ respondents feels sore on their throat. $5(12.20 \%, S D=0.33)$ respondents feels pain, 4 respondents $(9.76 \%, S D=0.30)$ experience fatigue and $3(7.32 \%, S D=0.27)$ sounded breathy. When these symptoms occur, it can last from 30 mins up to 5 days.

Alternately, respondents were asked how often they experience vocal discomfort in a year (Table 5). 78\% respondents experience at least once vocal discomfort in a year with breakdown of $14(35 \%, S D=0.48)$ respondents feels discomfort for $1-2$ times a year; 10 (25\%, $\mathrm{SD}=0.43)$ respondents feels discomfort for $3-4$ times and $7(17.5 \%, S D=0.38)$ respondents feels discomfort for up to 5 times and above in a year.

According to Table 5, a high percentage of $16(41.46 \%, S D=0.49)$ of respondents seek for medical attention after experiencing discomfort for $1-3$ days and $14(34.15 \%, S D=0.48)$ respondents choose not to seek for medical attention regardless of any discomfort, 7 (17.07\%, $\mathrm{SD}=0.38$ ) respondents seek for medication after experiencing discomfort for 4-6 days, 2 $(4.88 \%, \mathrm{SD}=0.22)$ respondents seek for medication after experiencing discomfort for 7-9 days lastly, $1(2.44 \%, S D=0.15)$ respondents will seek for medication after experiencing discomfort for more than 10 days.

In align with the data above, the following Table (Table 5) illustrate 27 (68\%) of the respondents knows where to seek medical assistance when their voice is having a problem; $13(31 \%)$ of the respondents are not aware of where to seek for medical help. 
Table 5 Voice Discomfort of Participants in a Year, Length of Time Before Seeking Medication

\begin{tabular}{lcccc}
\hline Variables & & Frequency $(\mathrm{n})$ & Percentage (\%) & Standard Deviation \\
\hline Frequency of voice & None & 9 & 22.5 & 0.45 \\
discomfort in a year & 1-2 times & 14 & 35.0 & 0.48 \\
& $3-4$ times & 10 & 25.0 & 0.43 \\
& $\geq 5$ times & 7 & 17.5 & 0.38 \\
Length of time before & None & 14 & 34.15 & 0.48 \\
seeing medical attention & $1-3$ days & 16 & 41.46 & 0.49 \\
& $4-6$ days & 7 & 17.07 & 0.38 \\
& $7-9$ days & 2 & 4.88 & 0.22 \\
Know where to seek & $\geq 10$ days & 1 & 2.44 & 0.15 \\
medical attention & Yes & 27 & 68 & - \\
\hline
\end{tabular}

\section{Discussion}

Findings from this present study revealed that teachers felt fatigued, their throat hurts, and they often speak too loud during teaching compared to daily conversation. These symptoms most probably occurred as a consequence of the high noise levels in the class. The primary schools in Klang Valley are crowded because these enjoining cities and towns have a high population density, as confirmed by the participants in this research, noting that each class had approximately 35-50 students, resulting in high classroom noise.

According to a study by Noraidah (2020), the standard noise level recommended by WHO (1999) is $55 \mathrm{~dB}(\mathrm{~A})$ for an occupied classroom. However, the mean level of noise in the primary school classrooms in Malaysia ranged from $60 \mathrm{~dB}(\mathrm{~A})$ to $76 \mathrm{~dB}(\mathrm{~A})$ (Ismail, Karim, \& Othman, 2020). Evidence from other studies was consistent with the present finding on the negative effect of high noise levels on voice symptoms (Kristiansen et al., 2014; Laukkanen et al., 2008). Further research can be done on the ideal number of students in a classroom to control the noise level.

This study also found that high percentage of teachers experience voice discomfort after a day of teaching. The most common symptoms were vocal dryness and soreness. These symptoms may cause increased tension in the larynx and develop inflammatory responses after long teaching hours (Remacle et al., 2018). Furthermore, the weather in Malaysia is hot and humid throughout the year since it is a country located near the equator, teachers may be dehydrated because of the weather or the use of air-conditional due to the weather (Santana, Masson, \& Araújo, 2017). Dehydration causes the vocal fold to be under-hydrated, while increasing the driving force of vibration while speaking. The increased vibration may cause tissue damage and render our voice more susceptible to vocal problems, especially dryness and soreness (Sivasankar \& Leydon, 2010).

This study concluded $68.28 \%$ of the teachers know where to seek medical attention; however, most teachers only seek medical help when the problem became severe or takes a long time to recover. The reason may be a lack of vocal hygiene knowledge. Teachers may not know how to start seeking help as the concept of vocal health was not very strong among 
teachers (Van Houtte, Claeys, Wuyts, \& Van Lierde, 2011; Weekly, Carroll, Korovin, \& Fleming, 2017). Worst, many teachers even consider vocal strain and discomfort part of the profession (Lee, Kim, \& Lee, 2018).

\section{Conclusion}

The research found that teachers often experience vocal fatigue, their throat hurts, and often speak too loudly when they are teaching compared to their daily conversation. $78 \%$ of teachers experience vocal discomfort at least once a year, and the most common vocal symptoms teachers suffered include vocal dryness, soreness, and pain after full-day teaching. When such symptoms developed, $34.5 \%$ of teachers choose not to seek medical help, and many only seek medical attention when the symptoms were prolonged.

As a consequence of not seeking medical help, the chances of teachers developing voice disorder increased, which cause harm not only to their physical well-being but also their emotional and social well-being; some studies showed that voice disorders lower teachers' self-esteem and lead to social isolation and depression (Rocha et al., 2021; Yildiz et al., 2020). The outcome of this study revealed that this possible mental issue derive from vocal problem was taken lightly by many Malaysian teachers. Teachers should face this problem with positive attitude and to be more proactive in taking medical action at the start of their vocal symptoms.

Based on the outcomes from this research, an alarming alert should be raised to all educationists, including teachers, school administrators, and all the stakeholders. Vocal hygiene knowledge should be embedded into teachers' training programs, schools' admins should take note on the classroom size and help create or maintain a teaching environment with lower environmental noise, and architects should help build schools' classrooms with better acoustic considerations, policy makers should make relevant policies to reduce current noise level to the standards as recommended by WHO. With this effort, it will provide and encourage a healthy working environment for teachers.

Teachers should take proactive effort to improve their vocal problems; a vocal hygiene program covering the concept of vocal health and vocal health practices may effectively reduce or prevent teachers' vocal symptoms, teachers should engage themselves in programs as such and embedding it to their lifelong vocalizing habits. In addition, a voice rehabilitation protocol can be introduced to the teachers who are affected by vocal problems, research on the effectiveness on these therapeutic protocols should also be traced.

\section{References}

Abdul Rahman, H. (2016). Prevalence of Voice Disorder Among Primary School Teachers in Bintulu, Sarawak. Malaysian Journal of Public Health Medicine (Vol. 16). Retrieved from http://www.mjphm.org.my/mjphm/journals/2016 - Volume 16 (Suppl. 2)/PREVALENCE OF VOICE DISORDER AMONG PRIMARY SCHOOL TEACHERS IN BINTULU SARAWAK.pdf

De Brito Mota, A. F., Giannini, S., de Oliveira, I. B., Paparelli, R., Dornelas, R., \& Ferreira, L. P. (2019). Voice Disorder and Burnout Syndrome in Teachers. Journal of Voice, 33(4), 581.e7-581.e16. https://doi.org/10.1016/j.jvoice.2018.01.022

Devadas, U., Bellur, R., \& Maruthy, S. (2017). Prevalence and Risk Factors of Voice Problems Among Primary School Teachers in India. Journal of Voice, 31(1), 117.e1-117.e10. 
https://doi.org/10.1016/j.jvoice.2016.03.006

Ismail, N. B., Karim, K., \& Othman, N. A. (2020). View of Noise Levels in Malaysia Primary: Are We Meeting the International Standards? International of Allied Health Sciences, 4(2), 1140-1150. Retrieved from https://journals.iium.edu.my/ijahs/index.php/IJAHS/article/view/176/369

Kristiansen, J., Lund, S. P., Persson, R., Shibuya, H., Nielsen, P. M., \& Scholz, M. (2014). A study of classroom acoustics and school teachers ' noise exposure, voice load and speaking time during teaching, and the effects on vocal and mental fatigue development. International Archives of Occupational and Environmental Health, 87(8), 851-860. https://doi.org/10.1007/s00420-014-0927-8

Laukkanen, A., Iloma, I., Leppa, K., \& Vilkman, E. (2008). Acoustic Measures and Self-reports of Vocal Fatigue by Female Teachers. Journal of Voice, 22(3), 283-289. https://doi.org/10.1016/j.jvoice.2006.10.001

Lee, Y.-R., Kim, H.-R., \& Lee, S. (2018). Effect of teacher's working conditions on voice disorder in Korea: a nationwide survey. Annals of Occupational and Environmental Medicine, 30, 43. https://doi.org/10.1186/s40557-018-0254-8

Nallamuthu, A., Boominathan, P., Arunachalam, R., \& Mariswamy, P. (2021). Outcomes of Vocal Hygiene Program in Facilitating Vocal Health in Female School Teachers With Voice Problems. Journal of the Voice Foundation. https://doi.org/10.1016/j.jvoice.2020.12.041

Nazari, M., Dastoorpoor, M., Ghasemzadeh, R., \& Moradi, N. (2020). Relationship Between Work Engagement and Voice Complaints Among Elementary School Teachers. Journal of the Voice Foundation. https://doi.org/10.1016/j.jvoice.2019.12.001

Nusseck, M., Spahn, C., Echternach, tmatthias, Immerz, A., \& Richter, B. (2020). Vocal Health, Voice Self-concept and Quality of Life in German School Teachers. Journal of the Voice Foundation, 34(4), 488.e29-488.e39. https://doi.org/10.1016/j.jvoice.2018.11.008

Porcaro, C. K., Howery, S., Suhandron, A., \& Gollery, T. (2019). Impact of Vocal Hygiene Training on Teachers' Willingness to Change Vocal Behaviors. Journal of Voice. https://doi.org/10.1016/j.jvoice.2019.11.011

Remacle, A., Garnier, M., Gerber, S., David, C., Petillon, C., Martin, S., \& Cedex, H. (2018). Vocal Change Patterns During a Teaching Day: Inter-and Intra-subject Variability. Journal of the Voice Foundation, 32(1), 57-63. https://doi.org/10.1016/j.jvoice.2017.03.008

Remacle, A., Morsomme, D., \& Finck, C. (2014). Comparison of Vocal Loading Parameters in Kindergarten and Elementary School Teachers. Journal of Speech, Language, and Hearing Research, 57(2), 406-415. https://doi.org/10.1044/2013

Roy, N. (2004). Voice Disorders in Teachers and the General Population: Effects on Work Performance, Attendance, and Future Career Choices. Journal of Speech, Language, and Hearing Research, 47(3), 542-551. https://doi.org/10.1044/vvd21.2.71

Santana, É. R., Masson, M., \& Araújo, T. M. (2017). The Effect of Surface Hydration on Teachers' Voice Quality: An Intervention Study. Journal of Voice, 31(3), 383.e5383.e11. https://doi.org/10.1016/j.jvoice.2016.08.019

Sathyanarayan, M., Boominathan, P., \& Nallamuthu, A. (2018). Vocal Health Practices Among School Teachers: A Study From Chennai, India. Journal of Voice, 33(5), 812.e1812.e7. https://doi.org/10.1016/j.jvoice.2018.04.005

Sivasankar, M., \& Leydon, C. (2010). The role of hydration in vocal fold physiology. Current 
Opinion in Otolaryngology \& Head and Neck Surgeryl, 18(3), 171-175. https://doi.org/10.1097/MOO

Smith, E., Gray, S. D., Dove, H., Kirchner, L., \& Heras, T. (1997). Frequency and Effects of Teachers' Voice Problems (Vol. II, No. I). Retrieved from http://cyber.scihub.tw/MTAuMTAxNi9zMDg5Mi0xOTk3KDk3KTgwMDI3LTY=/10.1016\%40s08921997\%2897\%2980027-6.pdf

Sundram, E. R., Norsa'adah, B., Mohamad, H., Ming Moy, F., Husain, N. R. N., \& Shafei, M. N. (2019). The Effectiveness of a Voice Care Program Among Primary School Teachers in Northeastern Malaysia. Oman Medical Journal, 34(1), 49-55. https://doi.org/10.5001/omj.2019.08

Van Houtte, E., Claeys, S., Wuyts, F., \& Van Lierde, K. (2011). The Impact of Voice Disorders Among Teachers: Vocal Complaints, Treatment-Seeking Behavior, Knowledge of Vocal Care, and Voice-Related Absenteeism. Journal of Voice, 25(5), 570-575. https://doi.org/10.1016/j.jvoice.2010.04.008

Vertanen-Greis, H., Loyttyniemi, E., \& Uitti, J. (2020). Voice Disorders are Associated With Stress Among Teachers: A Cross-Sectional Study in Finland. Journal of Voice, 34(3), 488.e1-488.e8. https://doi.org/10.1016/j.jvoice.2018.08.021

Weekly, E. M., Carroll, L. M., Korovin, G. S., \& Fleming, R. (2017). A Vocal Health Survey Among Amateur and Professional Voice Users. Journal of Voice, 32(4), 474-478. https://doi.org/10.1016/j.jvoice.2017.07.012

Yildiz, M. G., Bilal, N., Kara, I., Sagiroglu, S., Orhan, I., \& Doganer, A. (2020). Voice Disorders in Lower Primary School Teachers: An Observational Study. Journal of Voice : Official Journal of the Voice Foundation. https://doi.org/10.1016/j.jvoice.2020.12.001 